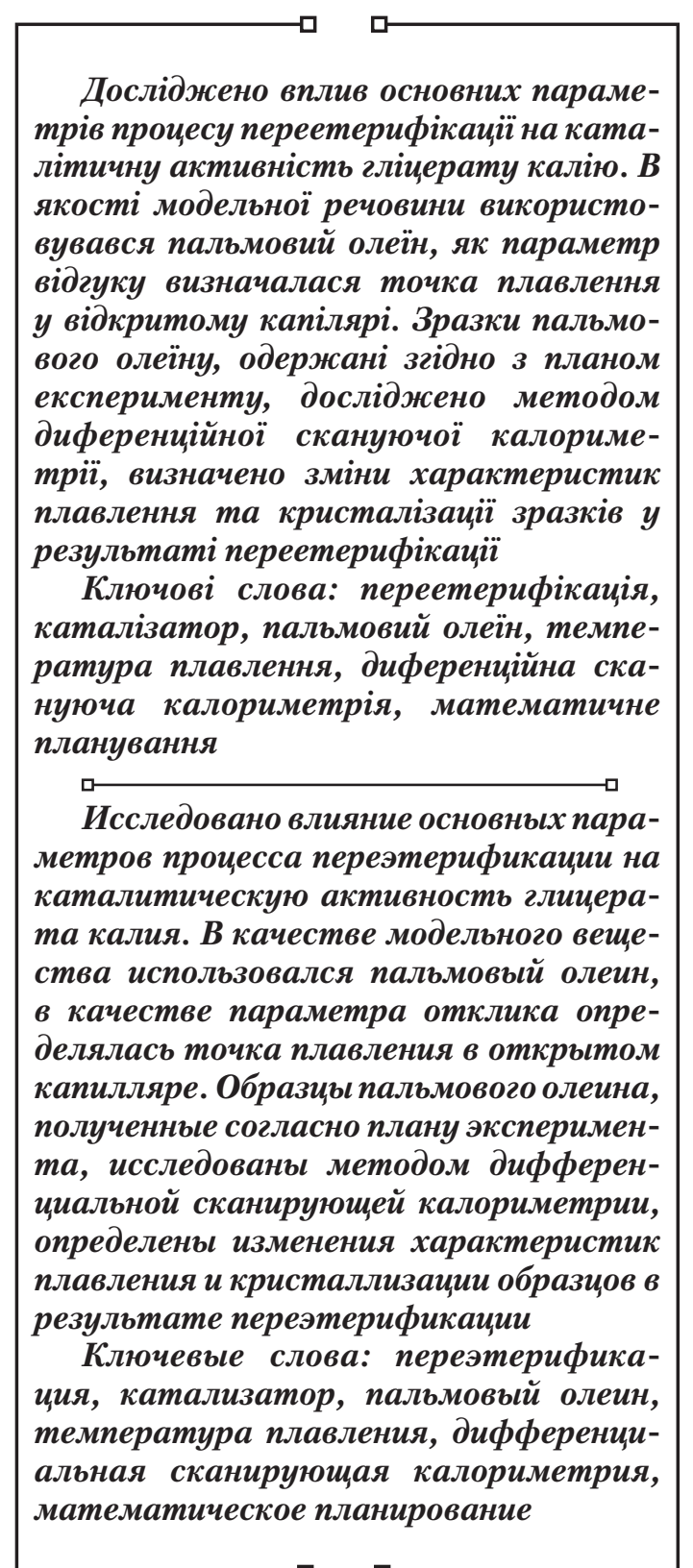

UDC 665.1

DOI: $10.15587 / 1729-4061.2016 .71236$

A STUDY OF FAT INTERESTERIFICATION PARAMETERS' EFFECT ON THE CATALYTIC REACTION ACTIVITY OF POTASSIUM GLYCERATE

\author{
N. Sy tnik
}

Research Assistant*

E-mail: natalya.sytnik.87@mail.ru

I. De midov

Doctor of technical sciences, Professor, Head of the Laboratory*

E-mail: demigon@rambler.ru

E. K u n i t s a

$\mathrm{PhD}$, Scientific Worker**

E-mail: ekaterina.kunitsia@gmail.com

V. Mazaeva

Research Assistant*

E-mail: tori-198919@yandex.ua

O. Ch u mak

$\mathrm{PhD}$, Professor**

E-mail: opchumak@mail.ru

* Laboratory of studies of fats chemistry

of oils and fats production

Ukrainian Research Institute of Oils and

Fats National Academy of Agrarian Sciences of Ukraine

Dziuba ave., 2a, Kharkiv, Ukraine, 61019

**Department of Technology of fats and fermentation products National Technical University "Kharkiv Polytechnic Institute"

Bagaliya str., 21, Kharkiv, Ukraine, 61002

\section{Introduction}

Nowadays, there is a tendency to create physiologically functional fatty foods that are characterized by a low content of saturated fatty acids, an increased proportion of polyunsaturated fatty acids, exclusion of cholesterol-containing raw materials, increased biological value, and certain given flavouring properties [1]. Moreover, fatty materials are replaced by vegetable oils, which are the main source of polyunsaturated fatty acids, phospholipids, fat-soluble vitamins, and other biologically active substances [2]. Currently, production of many fat-containing foods is largely based of using modified fats.

Modern methods of modifying edible fats include hydrogenation and hydrointeresterification, chemical and enzymatic interesterification, fractionation, mixing, and blending [3] Among these methods, interesterification is fundamentally distinguished as an instrument of modifying fats to obtain high-quality fatty products without changing the fatty acid composition of fats. The resulting products meet the require- ments of healthy nutrition and are appropriate both for direct consumption and for use in the baking industry to produce confectionery, canned food, pharmaceuticals, etc. [4, 5]. Interesterification requires to apply catalysts, among which the most common are sodium ethoxide and sodium methoxide. The use of these substances is associated with many difficulties [6], thus making it expedient to develop and introduce new effective and more affordable catalysts for interesterification of fats.

\section{Analysis of previous studies and statement of the problem}

Sodium methylate and sodium ethoxide, which are used in the food industry as catalysts for interesterification of fats, have several shortcomings, including permanent lose of catalytic activity even during a short time of storage or transportation. They are quite dangerous substances in terms of safety. These compounds have high reactivity even at room temperature and can create explosive dust [7]. According to current research, 
the risk of fires and explosions at industrial plants is a topical issue that requires a detailed study of the working conditions and the use of substances needed in production processes [8].

Chemical interesterification of oils and fats also involves the use of alkali metals (sodium and potassium) and alkali metal hydroxides (sodium or potassium). Alkali metals have high reactivity and quickly lose their catalytic activity. Alkaline hydroxides are less active than the alkali metals, their alloys and alkoxides, and, therefore, require higher process temperature (above $150{ }^{\circ} \mathrm{C}$ ), which may lead (albeit to a small extent) to undesirable secondary processes such as the formation of transisomers of fatty acids [9]. In [10], zirconium compounds are studied as possible catalysts for interesterification of fats.

In [11], sodium glycerate is described as an expedient catalyst in the interesterification reaction of rapeseed oil with methanol to produce biodiesel, since the cost of this catalyst is much less than that of traditional alkaline catalysts.

A comparison of the effectiveness of using sodium methylate and potassium as well as sodium hydroxide and potassium as catalysts for interesterification has proved that much of hydroxides of both sodium and potassium is spent on saponification of fatty material, which reduces the degree of converting triacylglycerols in the reaction of interesterification; thus, it is necessary to choose such catalysts that would minimize soap formation [12].

Among the existing catalysts, the most active is the classic one - sodium methylate, though its production and use are complicated by explosion and fire risks [13]. Therefore, the suggested alternative method of producing this catalyst, with sodium hydroxide and non-volatile, non-toxic substances polyols; the derived product is sodium methoxide with a small amount of sodium hydroxide [14].

Thus, it is still necessary to solve the problem of producing and using an effective, more accessible and safer catalyst for interesterification of fats.

\section{Research aim and objectives}

The aim of the research is to determine rational conditions of interesterification of fats with potassium glycerate. In view of the aim, it is important to achieve the following objectives:

- to carry out the interesterification reaction of palm olein in the presence of potassium glycerate according to each experiment in the planning matrix;

- to study the initial and interesterified samples of palm olein by differential scanning calorimetry (DSC) and to determine the characteristics of melting and crystallization of each sample;

- to make a comparison of the data on the melting temperatures of the samples determined in an open capillary and by DSC;

- to reveal the optimal conditions for the process of interesterification of fats in the presence of potassium glycerate.

\section{Materials and methods of studying the rational conditions of the interesterification process}

\section{1. Experimental materials and equipment}

In this study, the following reagents and materials were used:

- palm olein - refined, bleached, and deodorized according to ISO 4438:2005 (CODEX-Stan 210);
- open glass capillaries according to ISO 6321:2003 (ISO 6321:1991, IDT);

- liquid nitrogen according to GOST 9293:2009 (ISO 2435-73)

\section{2. Research methodology}

Temperature, process duration and catalyst concentration are the key parameters of carrying out interesterification reactions that affect the completeness of the process in the initial fat. Since the change in the melting temperature of palm olein corresponds to the change in the triacylglycerol content as a result of ineresterification [15] and if the interesterified substance is palm olein for which the melting point has increased by $(12-14){ }^{\circ} \mathrm{C}$, the use of the melting point as an initial parameter helps control the effectiveness of the process. At each point of the experiment, there is a variation of the selected factors revealing varying extents of reaction and different melting temperatures for palm olein. The use of a central composite design (CCD) of the second order orthogonal plan allows obtaining a nonlinear model of the process by which it is possible to set the optimum output parameter values for certain input variables. After the reaction, the catalytic residue was removed by means of adsorption purification, using an adsorbent Tonsil Standard $310 \mathrm{FF}$ at a temperature of $90{ }^{\circ} \mathrm{C}$, with the adsorbent dosage of $2 \%$ by the weight of olein.

The melting point of palm olein was determined in an open capillary (the flow point) in accordance with ISO 6321:2003 (ISO 6321:1991, IDT). The DSC study of palm olein was conducted according to the relevant guidance on the use of differential scanning calorimeters.

\section{The results of studying the rational conditions of interesterification in the presence of potassium glycerate}

Table 1 shows the basic level and the intervals of varying the factors, whereas Table 2 reflects the experimental $\left(\mathrm{y}_{\exp }\right)$ and calculated $\left(\mathrm{y}_{\text {calc }}\right)$ values of the response function.

Table 1

The main level and intervals of varying the parameters of interesterification

\begin{tabular}{|c|c|c|c|}
\hline \multirow{2}{*}{$\begin{array}{c}\text { The main } \\
\text { level, } \mathrm{x}_{\mathrm{j}}\end{array}$} & $\begin{array}{c}\text { The process } \\
\text { temperature } \\
\mathrm{x}_{1},{ }^{\circ} \mathrm{C}\end{array}$ & $\begin{array}{c}\text { The process } \\
\text { duration } \mathrm{x}_{2}, \mathrm{~h}\end{array}$ & $\begin{array}{c}\text { The catalyst } \\
\text { concentration (in } \\
\text { terms of the metal) } \\
\mathrm{x}_{3}, \%\end{array}$ \\
\cline { 2 - 4 } & 100 & 1 & 0.3 \\
\hline $\begin{array}{c}\text { Variation } \\
\text { intervals, } \Delta \mathrm{x}\end{array}$ & 15 & 0.5 & 0.2 \\
\hline
\end{tabular}

The processing of the obtained data had resulted in calculating the regression relationship between the melting point of palm olein and the process parameters. The assessment of the significance of regression coefficients was performed by Student's t-test (the tabular value, provided that 0.05 is significant, is 4.3 [16]). Table 3 shows the values of the calculated Student's t-test for each coefficient of the regression equation. 
The experimental and calculated values of the response function

\begin{tabular}{|c|c|c|c|c|c|c|c|c|c|c|c|c|c|c|c|}
\hline № & 1 & 2 & 3 & 4 & 5 & 6 & 7 & 8 & 9 & 10 & 11 & 12 & 13 & 14 & 15 \\
\hline $\mathrm{y}_{\exp }$ & 39.00 & 39.00 & 39.00 & 39.00 & 38.40 & 30.40 & 34.30 & 25.80 & 39.00 & 33.00 & 39.00 & 35.50 & 39.00 & 34.00 & 38.17 \\
\hline $\mathrm{y}_{\text {calc }}$ & 39.96 & 39.64 & 37.59 & 37.37 & 37.92 & 29.55 & 35.66 & 27.19 & 37.64 & 32.46 & 38.10 & 35.22 & 40.34 & 33.08 & 36.76 \\
\hline
\end{tabular}

Table 3

The estimated values of Student's t-test

\begin{tabular}{|c|c|c|c|c|c|c|c|c|c|c|c|}
\hline Designation & $\mathrm{t}_{0}$ & $\mathrm{t}_{1}$ & $\mathrm{t}_{2}$ & $\mathrm{t}_{3}$ & $\mathrm{t}_{12}$ & $\mathrm{t}_{13}$ & $\mathrm{t}_{23}$ & $\mathrm{t}_{123}$ & $\mathrm{t}_{11}$ & $\mathrm{t}_{22}$ & $\mathrm{t}_{33}$ \\
\hline Value & 181.7 & 9.4 & 5.1 & 13.1 & 0.2 & 7.6 & 4.0 & 0.2 & 6.1 & 0.8 & 2.1 \\
\hline
\end{tabular}

An importance condition for a factor to be judged as significant is that the values calculated by Student's t-test should be higher than the tabulated ones. Thus, the significant coefficients are those that have the variables $\mathrm{x}_{0}, \mathrm{x}_{1}, \mathrm{x}_{2}$, $\mathrm{x}_{3}, \mathrm{x}_{1} \cdot \mathrm{x}_{3}$, and $\mathrm{x}_{1}{ }^{2}$. The regression dependence in the natural values of the variables is the following:

$$
\begin{aligned}
& y=-55.3625-1.3511 \cdot x_{1}+2.366 \cdot x_{2}+ \\
& +83.915 \cdot x_{3}-0.6877 \cdot x_{1} \cdot x_{3}-0.005 \cdot x_{1}^{2}
\end{aligned}
$$

Fig. 1 shows the dependence of the melting temperature of palm olein on the process duration at the fixed values of the process temperature of $115^{\circ} \mathrm{C}$ and the catalyst concentration of $0.5 \%$. Fig. 2 reflects the palm olein melting temperature dependence on the process temperature at the fixed value of the process duration of 1.5 hours and the catalyst concentration of $0.5 \%$. Fig. 3 specifies the palm olein melting temperature dependence on the catalyst concentration at the fixed value of the process duration of 1.5 hours and the process temperature of $115^{\circ} \mathrm{C}$.

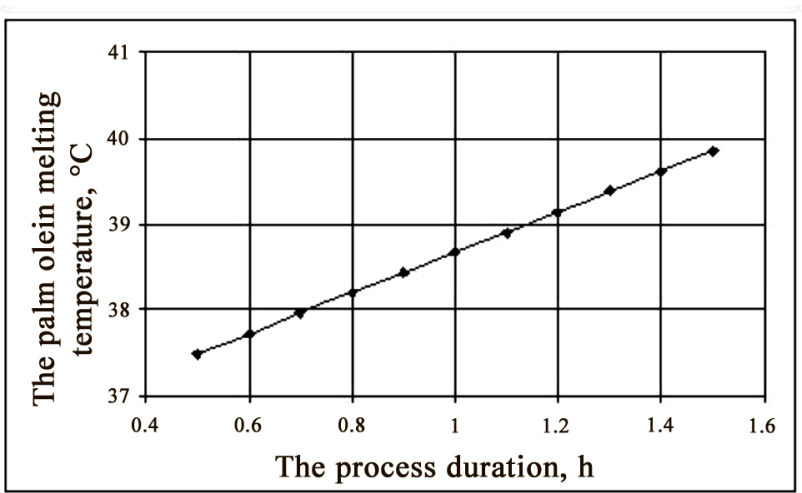

Fig. 1. The dependence of the palm olein melting temperature on the process duration

The intervals of varying the factors were selected according to the modes of interesterification of fats in the food industry in the presence of the most common catalysts - sodium methylate and sodium ethoxide. To improve the efficiency of the process, it is necessary to raise the temperature, extend the process duration, or increase the catalyst dosage. The use of the catalysts is aimed at reducing the process duration and temperature. Oils and fats can be interesterified at a temperature of at least $250{ }^{\circ} \mathrm{C}$, without a catalyst, but in this case the process is very slow and accompanied with other undesirable processes (isomerization, polymerization, and degradation) [3].

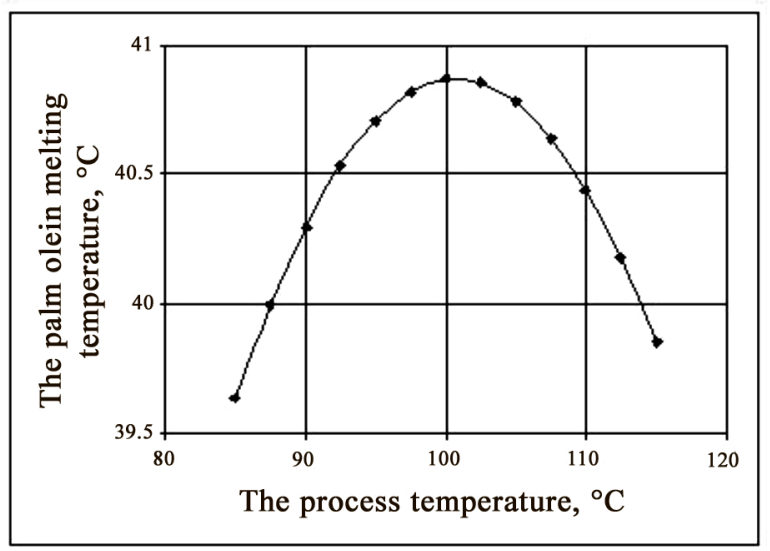

Fig. 2. The dependence of the palm olein melting temperature on the process temperature

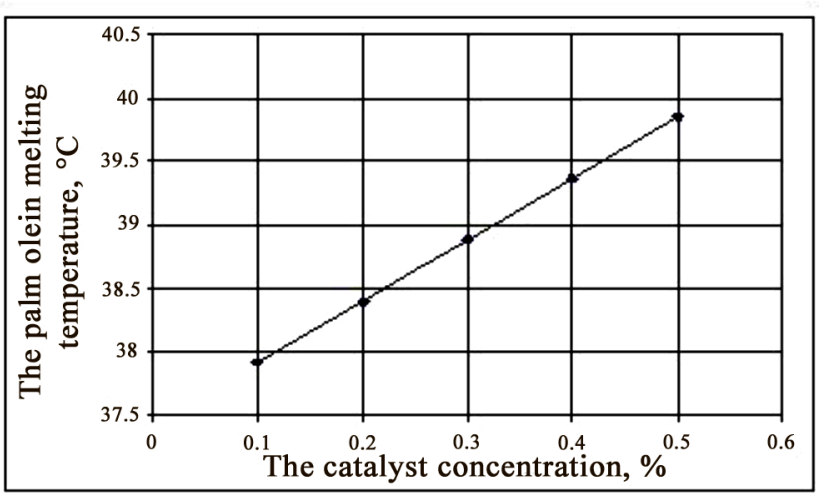

Fig. 3. The dependence of the palm olein melting temperature on the catalyst concentration

The graphic dependences shown in Fig. 1-3 can produce a conclusion that the maximum melting temperature of palm olein observed was $100{ }^{\circ} \mathrm{C}$ when the process had lasted for about 1.5 hours and the catalyst concentration was $0.5 \%$. Since it has been determined that palm olein becomes interesterified if the melting temperature increases by $(12-14){ }^{\circ} \mathrm{C}$ [15], the interesterification process can be considered effective at reaching this point of the melting temperatures difference. Thus, the values of the process parameters in which this condition is achieved can produce fat interesterification by using potassium glycerate as the catalyst. In particular, the temperature difference between the initial melting and the interesterified palm olein was observed as exceeding $12{ }^{\circ} \mathrm{C}$ when the catalyst concentration, most often used in interesterification, was $0.1 \%$, at a temperature of $100{ }^{\circ} \mathrm{C}$, and with the process duration of 1.5 hours. 
The initial palm olein and the samples interesterified according to the plan were studied by DSC, which is a group of methods of physical and chemical analysis to measure various heat processes: chemical reactions, phase transitions, and specific heat capacity $[17,18]$.

The undertaken research on the initial and interesterified samples of palm olein by using differential scanning calorimetry has resulted in a DSC thermogram revealing several peaks of melting and crystallization, with numeric values of extremes on the curve. The melting points of palm olein obtained in an open capillary were compared with the maximum temperature peaks on the melting curve of the DSC thermogram for each sample. The data are presented in Table 4 (sample No. 0 is the source palm olein, samples No. 1 to 15 correspond to the plan of the experiment, and the results on the melting temperatures for these samples are shown in Table 2). Fig. 4 shows a typical appearance of the DSC thermogram obtained for initial palm olein.

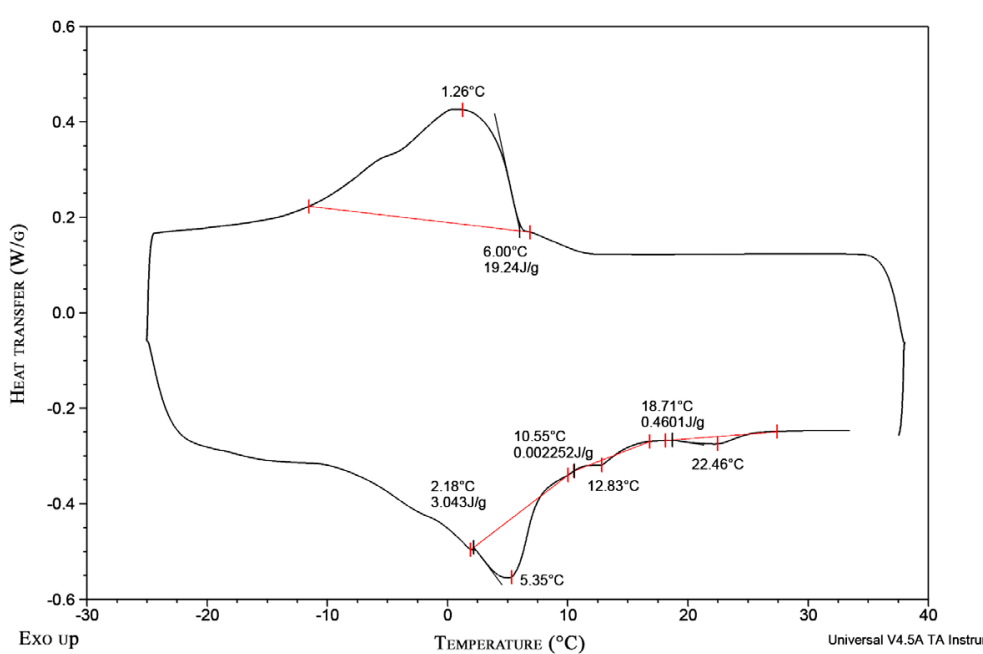

Fig. 4. The DSC thermogram of the initial palm olein

The values of the palm olein melting temperature as determined in an open capillary and the maximum temperature peaks in the DSC thermogram

\begin{tabular}{|c|c|c|c|c|c|c|c|c|}
\hline The sample number & 0 & 1 & 2 & 3 & 4 & 5 & 6 & 7 \\
\hline $\begin{array}{c}\text { The melting } \\
\text { temperature in a } \\
\text { capillary, }{ }^{\circ} \mathrm{C}\end{array}$ & 22.4 & 39 & 39 & 39 & 39 & 38.4 & 30.4 & 34.3 \\
\hline $\begin{array}{c}\text { The melting } \\
\text { temperature by a DSC } \\
\text { technique, }{ }^{\circ} \mathrm{C}\end{array}$ & 22.46 & 43.72 & 43.96 & 44.09 & 44.98 & 37.22 & 29.81 & 32.44 \\
\hline \begin{tabular}{c} 
The sample number \\
\hline $\begin{array}{c}\text { The melting } \\
\text { temperature in a } \\
\text { capillary, }{ }^{\circ} \mathrm{C}\end{array}$
\end{tabular} & 8 & 9 & 10 & 11 & 12 & 13 & 14 & 15 \\
\hline $\begin{array}{c}\text { The melting } \\
\text { temperature by a DSC } \\
\text { technique, }{ }^{\circ} \mathrm{C}\end{array}$ & 24.16 & 44.55 & 32.26 & 44.13 & 37.83 & 44.05 & 32.37 & 37.57 \\
\hline
\end{tabular}

Thus, the biggest difference between the melting temperatures in a capillary and the temperature peaks is observed for highly-fusible samples having a melting point of $39{ }^{\circ} \mathrm{C}$. Moreover, the peak temperature on the DSC thermogram exceeds in these cases the temperature determined in the capillary.
Table 4

\section{Discussion of the research findings on the nature of changes in the melting point of palm olein in the interesterification reaction in the presence of potassium glycerate at varying the process parameters}

According to the research findings, a longer process and a higher catalyst concentration induce a linear increase of the melting point of palm olein to coincide with the interesterification process completeness and to reflect catalyst effectiveness, and the maximum value of this index is observed at a temperature of $100{ }^{\circ} \mathrm{C}$. The results obtained for industrial conditions allow determining what factors and parameters can produce corresponding changes in raw materials during interesterification. Fatty products for different needs should have different properties and characteristics. For example, the melting point of cooking fats should be (28-36) ${ }^{\circ} \mathrm{C}$ according to ISO 4335:2004, but the interesterified fat of grade 2 should be melted at $(32-41){ }^{\circ} \mathrm{C}$ by ISO 4336:2004. Furthermore, using the obtained data, it is possible to estimate the cost of the resources and to make use of the properties of the raw materials to be processed. According to the obtained DSC thermograms, each sample is characterized by several peaks of phase transitions as a multi-component system consisting of triacylglycerol groups with different characteristics of melting and crystallization. Thus, it is possible to observe changes in the characteristics during the interesterification reaction. A significant difference between the melting points for highly-fusible samples measured in a capillary and the maximum temperatures of the peak extremes on the melting curve indicates that the flow point in the capillary is fixed under conditions of incomplete fusion of the sample. For samples with a melting point below $39^{\circ} \mathrm{C}$, there is a difference between the capillary melting temperatures and the melting peaks, but it is much smaller. In this respect, the flow points can be both below and above the extreme value of the melting peaks.

The present study has considered a wide range of values of the basic parameters in the interesterification process - temperature, duration, and catalyst concentration. This has made it possible to establish the conditions under which there is maximum completeness of the reaction that appears to change the melting temperatures for the model material used - palm olein. The research results can help make efficient use of resources and materials for interesterification, taking into account that the maximum melting temperature of palm olein has been observed at multiple values of each parameter. This allows choosing a shorter duration and lower temperatures as well as reducing the loss of the catalyst to achieve maximum efficiency of the process.

Previous studies, for example [19], attempted to determine changes in the performance of potassium glycerate as the catalyst on the basis of the process temperature and duration when the concentration of the catalyst was $0.1 \%$. It was determined that the palm olein melting point taken as a response function was maximum at the process temperature 
of $115^{\circ} \mathrm{C}$ and for a duration of 1.5 hours. However, the study revealed that the melting temperature under these conditions can be below the maximum; according to the research findings, the melting point can rise along with increasing values of the considered parameters (temperature and duration). Therefore, the decision was made that the interesterification factors should include concentration of the catalyst. Thus, the present study has been subsequent work aimed at finding rational conditions of the interesterification process.

\section{Conclusion}

1. Taking into account each point of a central composite design (CCD) of the second order orthogonal plan, a palm olein interesterification reaction was held in the presence of potassium glycerate, and the value of the output parameter the melting point - was determined for each sample in an open capillary (the flow point).

2 . The undertaken research on the initial and interesterified samples of palm olein by using differential scanning calorimetry (DSC) has revealed changes in the characteristics of the phase transitions in the samples of fat that was interesterified under various conditions; groups of triacylglycerols having different properties were found to appear and disappear in the samples as a result of interesterification under different conditions.

3. The biggest difference between the melting temperatures in the capillary and the maximum temperature peaks on the curves of DSC thermograms describing the process of melting is observed in highly-fusible samples for which the temperature of the extreme peak of the complete meltdown in the DSC thermogram exceeds the corresponding temperature specified in the capillary. There was an increase in the difference between the melting point of the palm olein samples in the open capillary and the DSC-determined thermogram when the melting point of the sample increased.

4. The study has determined that the maximum melting temperature of palm olein occurs during the interesterification process at a temperature of $100{ }^{\circ} \mathrm{C}$, with the process duration of 1.5 hours, and with the catalyst concentration of $0.5 \%$. For effective interesterification, it is possible to choose conditions that would be the most appropriate in each particular case depending on the required properties of the product and the needs of a particular enterprise. For example, the temperature difference between the initial melting and the interesterified palm olein was observed as exceeding $12{ }^{\circ} \mathrm{C}$ when the catalyst concentration, most often used in interesterification, was $0.1 \%$, at a temperature of $100{ }^{\circ} \mathrm{C}$, and with the process duration of 1.5 hours.

\section{References}

1. Voskonyan, O. S. Osnovnyie napravleniya i etapy sozdaniya emulsionnyh zhirovyh produktov [Text] / O. S. Voskonyan // Maslozhyrovaya promyshlennost. - 2012. - Vol. 6. - P. 16-17.

2. Baykov, V. G. Klassifikatsiya prirodnyh zhirov i ih himicheskiy sostav [Text] / V. G. Baykov // Maslozhyrovaya promyshlennost. 2007. - Vol. 3. - P. 44-45.

3. Paska, M. Z. Tekhnologiya margaryniv ta promyslovykh zhyriv [Text] / M. Z. Paska, I. M. Demydov, O. I. Zhuk. - Lviv: SPOLOM, 2013. $-187 \mathrm{p}$.

4. Noor Lida Habi Mat Dian. Interesterified palm products as hard stock for solid fat formulations [Text] / Noor Lida Habi Mat Dian, Kalyana Sundram Asman Ismail // MPOB Informatiom series. - 2006. - Vol. 323. - P. 330-331.

5. Waheed, A. Effect of interesterified palm and cottonseed oil blends on cookie quality [Text] / A. Waheed, G. Rasool, A. Asghar // Agriculture and Biology Journal of North America. - 2010. - Vol. 1, Issue 3. - P. 402-406. doi: 10.5251/abjna.2010.1.3.402.406

6. Demydov, I. M. Perspektyvni napryamky udoskonalennya pereeeteryfikatsiyi oliy ta zhyriv [Text] / I. M. Demydov, N. S. Sytnik, V. A. Gusak // Naukovo-praktychnyy zhurnal „Integrovani tekhnolohiyi ta energozberezhennya. - 2015. - Vol. 2. - P. 90-95.

7. Kwok, Q. Fire and explosion hazards related to the industrial use of potassium and sodium methoxides [Text] / Q. Kwok, B. Acheson, R. Turcotte, A. Janes, G. Marlair // Journal of Hazardous Materials. - 2013. - Vol. 250-251. - P. 484-490. doi: 10.1016/j.jhazmat.2013.01.075

8. Giby, J. Combustible dusts: A serious industrial hazard [Text] / J. Giby // Journal of Hazardous Materials - 2007. - Vol. 142, Issue 3. - P. 589-591. doi: 10.1016/j.jhazmat.2006.06.127

9. Nor Aini Idris. Interesterified palm products as alternatives to hydrogenation [Text] / Nor Aini Idris, Noor Lida Habi Mat Dian // Asia Pac. J. Clin. Nutr. - 2005. - Vol. 14, Issue 4. - P. 396-401.

10. Lopez, D. E. Esterification and transesterification using modified-zirconia catalysts [Text] / E. D. Lopez, J. G. Goodwin, D. A. Bruce, S. Furuta // Applied Catalysts A: General. - 2008. - Vol. 339, Issue 1. -P. 76-83. doi: 10.1016/j.apcata.2008.01.009

11. Bradley, D. Equilibrium studies of canola oil transesterification using a sodium glyceroxide catalyst prepared from a biodiesel waste stream [Text] / D. Bradley, E. Levin, C. Rodriguez, P. G. Williard, A. Stanton, A. M. Socha // Fuel Processing Technology. - 2016. Vol. 146. - P. 70-75. doi: 10.1016/j.fuproc.2016.02.009

12. Pisarello, M. L. Catalyst consumption during one and two steps transesterification of crude soybean oils [Text] / M. L. Pisarello, C. A. Querini // Chemical Engineering Journal. - 2013. - Vol. 234. - P. 276-283. doi: 10.1016/j.cej.2013.08.109

13. Kamali, S. K. Optimization of sunflower oil transesterification process using sodium methoxide [Text] / S. K. Kamali, C. P. Tan, T. C. Ling // The Science World Journal. - 2012. - Vol. 2012. - P. 1-8. doi: 10.1100/2012/475027

14. Martin, R. Development of sodium alkoxide catalysts from polyols [Electronic resource] / R. Martin, S. Ramaswami, D. Ajay, S. Phyllis, G. H. Yoong // Saskatchewan. - 2011. - Available at: http://ecommons.usask.ca/bitstream/handle/10388/ETD-201107-75/GOK-THESIS.pdf? sequence $=3$

15. Golodnjak, V. A. Opredelenie aktivnosti katalizatora himicheskoj pereeterifikacii zhirov [Text] / V. A. Golodnjak, I. N. Demidov, V. S. Mazaeva, N. S. Sytnik, P. F. Petik // Uralskij nauchnyj vestnik. - 2014. - Vol. 8, Issue 87. - P. 187-193. 
16. Bondar, A. G. Planirovanie eksperimenta pri optimizacii processov himicheskoj tehnologii [Text] / A. G. Bondar, G. A. Statjuha, I. A. Potjazhenko. - Kyiv: Vishha shkola, 1980. - 264 p.

17. Emelina, A. L. Differentsialnaya skaniruyuschaya kalorimetriya [Text] / A. L. Emelina. - Moscow: Laboratoriya himicheskogo fakulteta MGU, 2009. - 42 p.

18. Knothe, G. A comprehensive evaluation of the melting points of fatty acids and esters determined by differential scanning calorimetry [Text] / G. Knothe, R. O. Dunn // Journal of the American Oil Chemists' Society. - 2009. - Vol. 86, Issue 9. - P. $843-856$. doi: 10.1007/s11746-009-1423-2

19. Sytnik, N. S. DoslIdzhennya aktivnostI glitseratu kaliyu yak katalizatoru pereeterifikatsiyi zhiriv za riznih umov provedennya protsesu [Text] / N. S. Sytnik, I. M. Demydov, K. V. Kunitsa // Visnik Natsionalnogo tehnichnogo universitetu «KhPI». - 2016. Vol. 12, Issue 1184. - P. 188-193

Розроблено склади і досліджені властивості низьков'язких фурано-епоксидних олігомерів, які структуровані амінними затверджувачами для використання при ремонтно-відновлювальних будівельних роботах. Визначено діапазон оптимальних параметрів структурування полімерних систем. Досліджені структурно-топологічні параметри $і$ реакційна здатність вихіднх речовин при отриманні фураноепоксидних матеріалів. Проведено дослідження мічностних, адгезійних, сорбиійних властивостей розроблених низъков'язких фурано-епоксидних полімерів

Ключові слова: фурано-епоксидний олігомер, аміновмісткий затверджувач, адгезійні, сорбційні властивості, низъков'язка система

Разработаны составы и исследованы свойства низковязких фурано-эпоксидных олигомеров, структурируемых аминными отвердителями для использования при ремонтно-восстановительных строительных работах. Определен диапазон оптимальных параметров структурирования полимерных систем. Исследованы структурно-топологические параметры и реакционная способность исходных веществ при получении фурано-эпоксидных материалов. Проведено исследование прочностных, адгезионных, сорбционных свойств разработанных низковязких фурано-эпоксидных полимеров

Ключевые слова: фурано-эпоксидный олигомер, аминосодержащий отвердитель, адгезионные, сорбционные свойства, низковязкая система
UDC $678.5: 691.342$

DOI: $10.15587 / 1729-4061.2016 .71266$

\title{
DESIGNING LOW VISCOSITY FURAN- EPOXY POLYMERS OF THE MATERIALS FOR CONSTRUCTION INDUSTRY
}

\author{
A. Rassokha \\ $\mathrm{PhD}$, Associate Professor* \\ E-mail: rassan1958@rambler.ru \\ A. Cherkashina \\ $\mathrm{PhD}$, Associate Professor* \\ E-mail: annikcherkashina@gmail.com \\ *Department of Technology of Plastics and \\ biological active polymer \\ National Technical University \\ "Kharkiv Polytechnic Institute" \\ Bagalia str., 21, Kharkiv, Ukraine, 61002
}

\section{Introduction}

During fulfilling repairing and recovery work of the locally destroyed concrete or reinforced concrete elements of buildings and structures in the industrial and civil construction [1], the need arises of developing low-viscosity materials based on reactive monomer-oligomeric ingredients with high wetting and adhesive capacity to the dry and moist concrete and increased combination of the deformation-strength properties [2].

When creating polymeric composites, contemporary construction materials science is oriented towards priority application of the basic principles of "Green Chemistry"[3]. These principles allow designing materials and making a selection of the optimal parameters of the technological process of creating multicomponent polymeric composites of low viscosity at a fundamentally new technical level. In this case the targeted formation of a rational topological structure of the system is carried out at the micro-, meso- and macro structural levels of its organization.

The determining role in this process belongs to the concept, which combines technological efficiency of the process of obtaining a polymeric material, ecological safety in the operation of construction elements with a polymeric component and economic expediency of applying designed materials.

Therefore, the development and research into polymeric systems of low viscosity for the construction industry is an actual task and is a promising trend in the materials science of construction composite materials. 